\title{
ANALYSIS OF TASKS IN THE SLOVAKIAN BEBRAS CONTEST 2013/14
}

\section{Monika TOMCSÁNYIOVÁ - Peter TOMCSÁNYI}

\begin{abstract}
:
The seventh year of the Slovakian iBobor Contest took place this school year. It is the local version of the Bebras International Contest on Informatics and Computer Fluency. It is organized in five categories according to school classes. Our article analyzes the tasks of the Benjamin category (classes 5 to 7 , age 10 to 12). At first we describe the tasks and their results in general, next we concentrate on deeper analysis of a few selected tasks. Particularly we concentrated on one task that had the same topic as a task from last year's contest and on another task that turned out to be the hardest one in this year's contest in the Benjamin category. We have stated our hypotheses and then we tried to test them using the methods of statistical analysis as well as questionnaires for teachers and students. In the conclusion we try to draw some consequences for the organizers of future contests, as well as for the teachers preparing students for the contest.
\end{abstract}

Keywords: Bebras contest, category Benjamin, statistical analysis.

\section{ANALÝZA RIEŠENÍ ÚLOH SÚŤǍ̌E IBOBOR V ŠKOLSKOM ROKU 2013/14}

Resumé: V školskom roku 2013/14 sa uskutočnil už siedmy ročník sút’aže iBobor na Slovensku. Sútaž má pät' kategórií, v ktorých sú žiaci rozdelení do skupín podl'a jednotlivých tried. V našom príspevku analyzujeme úlohy kategórie Benjamíni. Najprv popisujeme všeobecne výsledky všetkých úloh, potom sa zameriame sa na hlbšiu analýzu niektorých vybraných úloh. Konkrétne na jednu úlohu, ktorá je podobná inej úlohe $\mathrm{z}$ minulého ročníka a na úlohu, s ktorou mali tento rok sút’ažiaci najväčšie problémy. $\mathrm{V}$ tejto súvislosti sme si stanovili hypotézy a snažíme sa ich overit' jednak štatistickou analýzou riešení úloh a odpovedí v ankete k sút'aži, jednak analýzou dotazníkov pre učitel'ov a anketových odpovedí sút’ažiacich. V závere sa snažíme o zhrnutie poznatkov jednak pre organizátorov pri zadávaní úloh 
v d’alších ročníkoch jednak pre učitelov, ktorí pripravujú svojich žiakov na sút’až.

Klíčová slova: Informatický bobor, kategória Benjamíni, analýza riešení úloh. 


\section{1 Úvod}

V školskom roku 2013/14 sa na Slovensku uskutočnil už siedmy ročník sút’aže Informatický bobor, skrátene iBobor. Je to slovenská verzia medzinárodnej sútaže Bebras, ktorá má svoj pôvod v Litve, kde sa tento rok konal už jej 10. ročník. Sút'aže sa tento rok konali v 24 krajinách a spolu sa zúčastnilo viac než 600000 sút'ažiacich.

V sút'aži iBobor sa tomto ročníku zúčastnilo 55017 sútažiacich z 899 škôl. Žiaci sú rozdelení podl’a triedy, ktorú navštevujú do piatich kategórií - Bobríci (3. a 4. ročník ZŠ), Benjamíni (5. až 7. ročník ZŠ), Kadeti (8. až 9. ročník ZŠ), Juniori (1. a 2. ročník SŠ) a Seniori (3. a 4. ročník SŠ).

V tomto článku sa venujeme sút’ažnej kategórii Benjamíni, v ktorej tento rok sút'ažilo 18168 žiakov z 5., 6. a 7. ročníka základnej školy alebo prímy a sekundy osemročných gymnázií.

Kvôli problémom so sútažným serverom sút'až prebehla $\mathrm{v}$ dvoch dňoch - $\mathrm{v}$ riadnom termíne sme museli sút'až prerušit' a vyhlásit' náhradný termín. Do výsledkov sme zahrnuli všetkých sút'ažiacich, ktorí sútažili $\mathrm{v}$ aspoň jednom z termínov. Ak sút’ažili dvakrát, počítal sa im len výsledok z náhradného termínu. V dôsledku toho sa vo výsledkoch objavili aj žiaci, ktorí $\mathrm{v}$ riadnom termíne nestihli vyriešit' všetky úlohy a zároveň už v náhradnom termíne nesút'ažili.
Mnohí z nich mali vel'ký počet neriešených úloh, čo ovplyvňovalo niektoré štatistické analýzy. Preto sme sa rozhodli vylúčit' $\mathrm{z}$ d'alšieho štatistického spracovania tých z nich, ktorí neriešili 5 alebo viac úloh. Takých sút'ažiacich bolo 741 . $\mathrm{V}$ tomto článku teda používame súbor údajov o riešeniach $17 \mathbf{4 2 7}$ sút'ažiacich.

Žiaci, riešili počas 40 minút 15 úloh. Názvy úloh sú uvedené v Tab. 1. Každá z nich je zaradená do okruhov informatiky podl'a Štátneho vzdelávacieho programu (ŠVP) pre 2. stupeň základnej školy (ISCED 2).

\begin{tabular}{|l|c|}
\hline BoborBook & SPOL \\
\hline Most & INF \\
\hline Panoramatická fotografia & INF \\
\hline Rodinný graf & INF \\
\hline Zmena textu & INF \\
\hline Kmeň stromu & INF \\
\hline Výt'ah & ALG \\
\hline Tunely & ALG \\
\hline Padajúce loptičky & ALG \\
\hline Zmrzlinový stroj & INF \\
\hline Hamburgery & INF \\
\hline Tri prstene & INF \\
\hline Robotická včela & ALG \\
\hline Lienka Lenka & ALG \\
\hline Dlažba & INF \\
\hline
\end{tabular}

Tab. 1: Názvy úloh kategórie Benjamíni a ich zaradenie do okruhov informatiky podl'a štátneho vzdelávacieho programu pre vzdelávací stupeň ISCED 2. 
V Štátnom vzdelávacom programe je určených pät' okruhov informatiky (pred názvom okruhu je skratka, ktorú sme si zvolili pre tento článok) INF - Informácie okolo nás, DG - Komunikácia prostredníctvom digitálnych technológií, ALG - Postupy, riešenie problémov, algoritmické myslenie, PC - Princípy fungovania digitálnych technológií a SPOL - Informačná spoločnost'. Z uvedenej tabul'ky úloh a ich zaradenia do okruhov je zrejmé, že niektoré okruhy informatiky nemajú zastúpenie medzi tohtoročnými úlohami. Jedným z dôvodov je to, že aj z medzinárodnej databázy prichádzajú úlohy, v ktorých nie sú zastúpené tieto okruhy informatiky, viac o príprave úloh pozri [1].

Jedna úloha (Rodinný graf) bola interaktívna a dve úlohy (Panoramatická fotografia a Dlažba) mali interaktívnu pomôcku, viac pozri [2].

Vd'aka interaktívnej pomôcke sa snažíme žiakom dat' do rúk nástroj na experimentovanie a možnost' vyskúšat' si riešit' úlohu tým, že manipulujú s objektami.

V úlohe Panoramatická fotografia mohli žiaci t'ahat' jednotlivé fotografie a prekrývat' ich tak, aby im nakoniec vznikla jedna fotografia.

V úlohe Dlažba mohli sút'ažiaci vyfarbovaním dlaždíc a metódou pokus-omyl zistit', akú farbu bude mat' označená dlaždica. Vd'aka tomu, že skúšali rôzne zafarbenia dlaždíc sa mohli presvedčit', že označená dlaždica musí mat' modrú farbu (vid' Obr. 1).
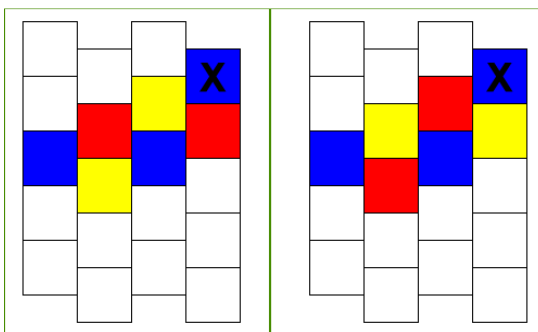

Obr. 1: Interaktívna pomôcka $v$ úlohe Dlažba a jej využitie na to, aby žiak zistil akú farbu bude mat' dlaždica označená písmenom X ak dodrží pravidlá ukladania dlaždíc.

Úlohy sú pred sút'ažou rozdelené do kategórií podl'a očakávanej obtiažnosti na l'ahké (prvých pät' úloh) stredné (druhých pät' úloh) a t’ažké (posledných pät' úloh). Očakávanú obtiažnost' určujeme na základe návrhu autora úloh a uváženia organizátorov, ked’že kvôli utajeniu úloh neorganizujeme pilotné testovanie.

Skutočná obtiažnost' úloh sa preto ukáže až po sút'aži a nezriedka sa líši od očakávanej obtiažnosti. Tento jav pozorujeme nielen na Slovensku, ale vo všetkých krajinách, ktorých výsledky sme mali možnost' vidiet' (napr. Česko, vid' [3] alebo Holandsko, vid' [4]). 


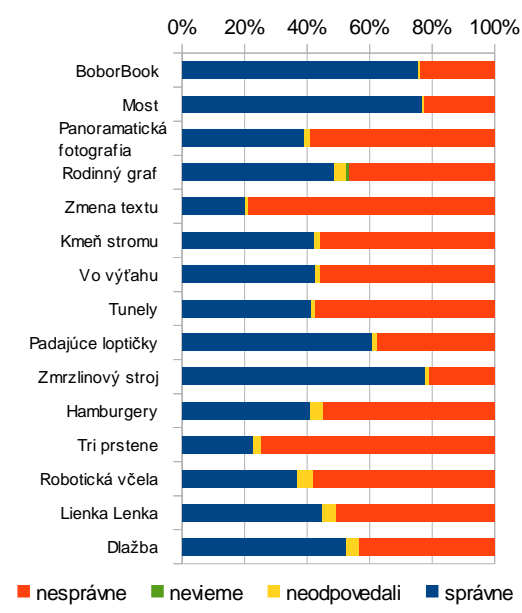

Obr. 2: Úspešnost’úloh. Vidíme, že tento rok sme vo viacerých prípadoch neodhadli správne skutočnú obtiažnost' úloh.

Obr. 2 ukazuje počet správnych odpovedí, počet nezodpovedaných úloh a počet nesprávnych odpovedí. Pri interaktívnych úlohách sa ešte môže stat', že počítač neodošle správne riešenie lebo nemá nainštalovaný Flash player alebo sa stane niečo iné nepredvídané. Takéto prípady sú na obrázku označené ako „nevieme“.

Obr. 3 dokumentuje rozdelenie počtu bodov od minimálneho zisku 0,05 bodu po maximum 80 bodov $\mathrm{v}$ štvorbodových intervaloch.
Benjamíni 2013/14 - rozdelenie počtu bodov

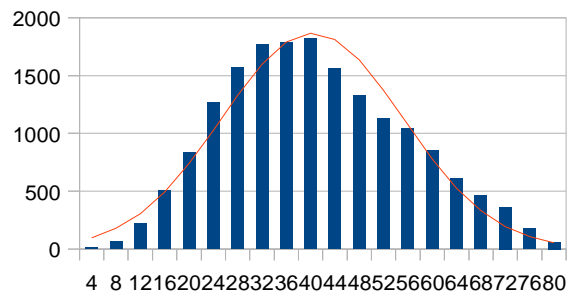

Obr. 3: Rozdelenie počtu bodov. Červená čiara je graf normálneho rozdelenia s rovnakým priemerom, počtom prvkov a rozptylom, ako majú naše údaje.

\section{Použité výskumné metódy}

V našom výskume, ktorý sa týka kategórie Benjamíni sa venujeme analýze riešení niektorých úloh. Vybrali sme si jednu úlohu, ktorá je podobná inej úlohe $\mathrm{z}$ minulého ročníka a jednu úlohu, s ktorou mali tento rok sút'ažiaci najväčšie problémy.

Ked’že vo výskume analyzujeme, triedime a vyhodnocujeme údaje zo sút'aže ide o empirický výskum typu ex post facto. Analyzujeme teda udalost', ktorá sa už stala (prebehla sút’až) a úlohy v nej použité neboli vyberané $s$ ohl'adom na akékol'vek konkrétne výskumné ciele.

Pre výskum, ktorý je predmetom tohto článku sme si špecifikovali 2 ciele. $\mathrm{Ku}$ každému $\mathrm{z}$ nich sme si stanovili hypotézy. Tie sme pri prvom cieli overovali pomocou štatistickej analýzy údajov $\mathrm{z}$ data- 
bázy, pri druhom analýzou vývoja zadania úlohy a zist'ovaním názorov učitel'ov a žiakov k tejto úlohe.

\section{Ciele výskumu a výskumné hypotézy}

Po ukončení sút’aže máme $\mathrm{v}$ databáze $\mathrm{k}$ dispozícii riešenia všetkých žiakov. Pomocou filtrovania $\mathrm{z}$ nich vieme vyberat' len niektoré úlohy alebo len žiakov s nejakou charakteristikou ich riešení (napr. takých, ktorí sú úspešní riešitelia, ktorí riešili konkrétnu úlohu správne a podobne). Analýzou týchto údajov sme sa snažili odhalit' niektoré zaujímavé poznatky o úlohách a ich riešeniach, ktoré by pomohli jednak organizátorom pri zadávaní úloh v d’alších ročníkoch jednak učitel'om, ktorí pripravujú svojich žiakov na sút'až.

Ciel' 1: Vyhl'adanie jednej úlohy $\mathrm{z}$ minuloročnej a jednej úlohy z tohtoročnej sút'aže, ktoré boli typovo podobné a skúmanie ich úspešnosti u žiakov, ktorí riešili obe tieto úlohy. Našli sme takú dvojicu úloh - Prefarbi a Kmeň stromu.

Hypotéza 1A: Ak žiaci riešili minuloročnú úlohu nesprávne, zvolia si možnost' „,neodpovedat'“.

Hypotézou si chceme overit', či si dostatočne vel'a žiakov počas sút'aže uvedomilo, že $\mathrm{v}$ minulom ročníku riešili podobnú úlohu a odpovedali nesprávne, a teda bude pre nich lepšie, ak si teraz radšej zvolia možnost' neodpovedat' a nestratia tak body v sút'aži.
Hypotéza 1B: Ak si žiaci v minulom školskom roku vybrali možnost' na úlohu ,neodpovedat'“, bud' na tohtoročnú úlohu odpovedia správne alebo si opät' vyberú možnost' ,neodpovedat"“.

Overením hypotézy 1B sa snažíme sledovat' správanie žiakov pri výbere možnosti neodpovedat' na niektorú otázku. V tomto prípade si chceme overit', že ak žiaci počas minuloročnej sút'aže uvažovali nad riešením úlohy a cielene si zvolili možnost' neodpovedat', tak sú si počas tohtoročnej sútaže istí svojou odpoved'ou alebo si opät' vyberú možnost' ,neodpovedat"“.

Ciel' 2: Vyhl'adanie takej úlohy z tohtoročnej sút’aže, o ktorej sme predpokladali, že bude pre žiakov lahšia než sa ukázalo v sút'aži. $\mathrm{V}$ tomto ročníku to bola úloha

\section{Zmena textu.}

Hypotéza 2: Predpokladáme, že žiaci nepochopili vysvetlenie fungovania tlačidiel.

Na overenie tejto hypotézy, sme analyzovali odpovede žiakov v žiackej ankete a oslovili sme učitel'ov, aby sa vyjadrili, prečo sa domnievajú, že túto úlohu nesprávne vyriešili.

Analýzou odpovedí hl'adáme príčinu nesprávneho riešenie úlohy, aby sme sa $\mathrm{v}$ budúcich ročníkoch sút'aže vyvarovali chýb, ktoré vznikli pri formulácii zadania úlohy.

V súvislosti s touto úlohou, okrem overenia stanovenej hypotézy, v článku diskutujeme o tom, akým 
spôsobom sa úloha menila počas revidovania úloh na medzinárodnom stretnutí a tiež na stretnutiach tímu, ktorý pripravoval úlohu do slovenskej sút’aže.

\section{Ciel' 1 - dve úlohy $z$ dvoch ro- kov}

$\mathrm{V}$ minulom ročníku bola v kategórii Bobrík úloha Prefarbi. Bola zaradená ako t’ažká a analýza výsledkov toto zaradenie potvrdila, správne ju vyriešilo len $21 \%$ sút’ažiacich.

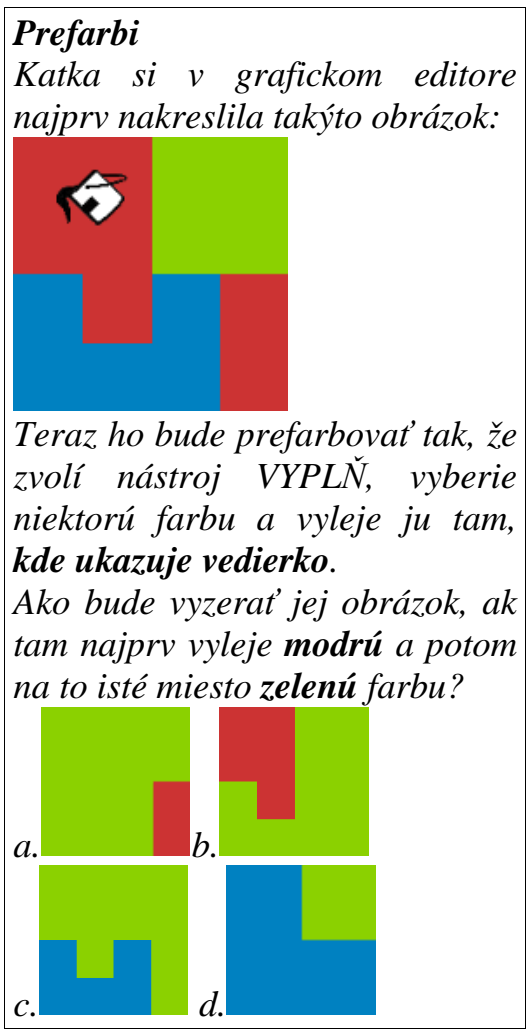

Tento rok sme mali v kategórii Benjamín úlohu, ktorej teoretické pozadie bolo rovnaké - pochopenie vypĺn̆ania v bitmapovom grafickom editore. Je to úloha Kmeň stromu. Bola zaradená ako stredne t’ažká a výsledky toto zaradenie taktiež potvrdili (úspešnost’ $42 \%$ ):

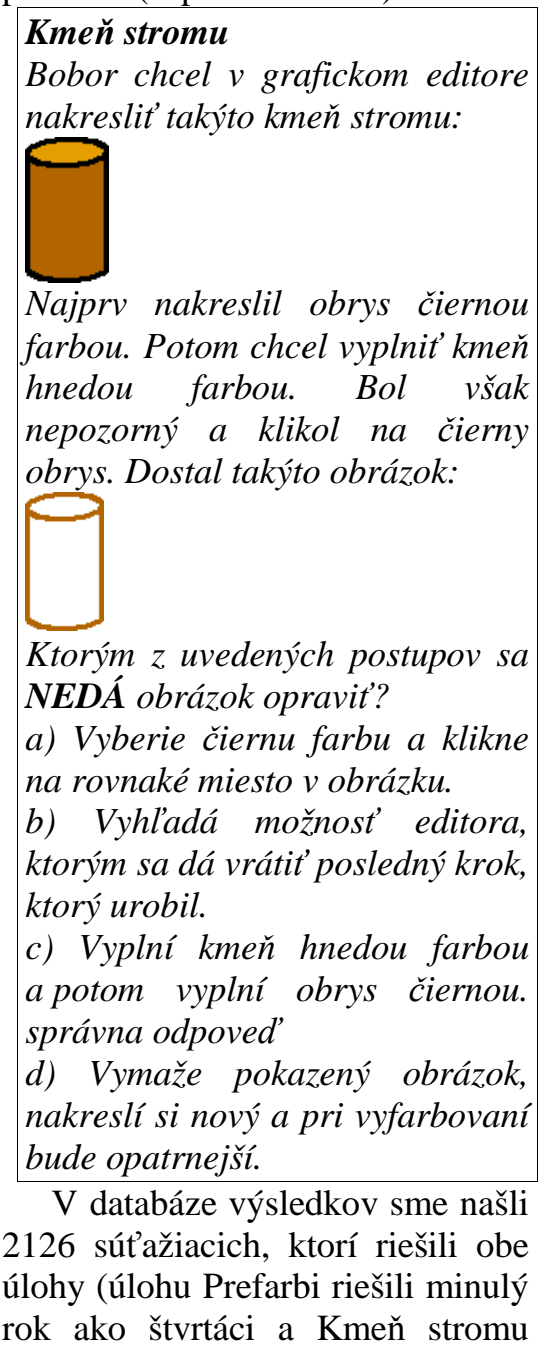

Bobor chcel v grafickom editore nakreslit' takýto kmeň stromu:

Najprv nakreslil obrys čiernou farbou. Potom chcel vyplnit' kmeň hnedou farbou. Bol však nepozorný a klikol na čierny obrys. Dostal takýto obrázok:

Ktorým z uvedených postupov sa NEDÁ obrázok opravit?

a) Vyberie čiernu farbu a klikne na rovnaké miesto $v$ obrázku.

b) Vyhl'adá možnost' editora, ktorým sa dá vrátit' posledný krok, ktorý urobil.

c) Vyplní kmeň hnedou farbou a potom vyplní obrys čiernou. správna odpoved

d) Vymaže pokazený obrázok, akresti si novy a pri vyfarbovani bude opatrnejst.

databáze výsledkov sme našl úlohy (úlor rok ako štvrtáci a Kmeň stromu 
tento rok už ako ako piataci). Zaujímalo nás, či dokážeme nájst' nejaký vzt’ah medzi riešením týchto dvoch úloh v tejto skupine žiakov.

Pred testovaním našich konkrétnych hypotéz sme si zostavili kontingenčnú tabul'ku z riešení oboch úloh, ako aj znamienkovú schému kontingenčnej tabul'ky. Postupovali sme podl'a literatúry [5]. Pre zamietnutie nulovej hypotézy si stanovujeme hladinu významnosti 0,05 .

\begin{tabular}{|c|c|c|c|c|}
\hline & \multicolumn{3}{|c|}{ Kmeň stromu } & \\
\hline Prefarbi: & nič & zle & dobre & spolu \\
\hline nič & 3 & 34 & 38 & 75 \\
\hline zle & 33 & 939 & 532 & 1504 \\
\hline dobre & 8 & 272 & 267 & 547 \\
\hline spolu & 44 & 1245 & 837 & 2126 \\
\hline
\end{tabular}

hodnota $\chi^{2}: 36,74$

hladina významnosti:

2E-007

Znamienková schéma:

\begin{tabular}{l|c|c|c|}
\hline & \multicolumn{3}{|c|}{ Kmeň stromu } \\
\hline Prefarbi: & nič & zle & dobre \\
\hline nič & $\mathbf{0}$ & - & + \\
\hline zle & $\mathbf{0}$ & $\mathbf{+ + +}$ & -- \\
\hline dobre & $\mathbf{0}$ & -- & +++ \\
\hline
\end{tabular}

Tab. 2: Kontingenčná tabul'ka riešení úloh Prefarbi a Kmeň stromu. Pre skrátenie zápisu sme v tejto aj nasledujúcich tabul'kách použili slová nič, zle a dobre namiesto neodpovedali, nesprávne a správne.

Výsledky štatistickej analýzy (vypočítaná hladina významnosti je $2.10^{-7}$ ) nás oprávňujú prijat' hypotézu, že existuje štatisticky výz- namný vzt’ah medzi riešením úlohy Prefarbi a riešením úlohy Kmeň stromu. Zo znamienkovej schémy vidíme, že podstatne väčšiu než očakávanú početnost' mala kombinácia zle-zle (teda, že sút’ažiaci nevyriešil správne ani jednu $\mathrm{z}$ nich) a dobre-dobre (sút’ažiaci vyriešil správne obe úlohy).

Možnou (pesimistickou) interpretáciou týchto faktov je to, že sút'ažiaci sa za rok strávený na hodinách informatickej výchovy a informatiky nedozvedeli viac o tom, ako funguje vyfarbovanie v bitmapových editoroch a neúspech $\mathrm{v}$ riešení úlohy spred roka ich nemotivoval dozvediet' sa niečo viac z danej oblasti.

Vidíme však aj, že aj počet kombinácií riešení nič-dobre (minulý rok neodpovedal, tento rok mal správnu odpoved') je mierne vyššia než očakávaná. Aj ked' ide o malý počet sút’ažiacich, dáva nám to istú nádej, že aspoň tí, čo minulý rok úlohu naschvál vynechali, sa za ten rok niečo viac dozvedeli a vyriešili ju vo väčšej miere správne.

Odpoved' na naše dve hypotézy sme hl'adali pomocou kontingenčných tabuliek, ktoré zlučujú niektoré políčka Tab. 2 .

Pre overenie hypotézy 1A sme zostavili Tab. 3. Vypočítaná hodnota testovacieho kritéria $\chi^{2}$ je 0,393 a vypočítaná hladina významnosti je 0,5305. Ked'že je vyššia než zvolená hladina významnosti 0,05 , nemôžeme zamietnut' nulovú hypo- 
tézu, teda nemôžeme potvrdit' našu hypotézu 1A. Nemôžeme teda povedat', že by sút'ažiaci mali tendenciu neriešit' úlohu ked' ju mali minulý rok zle.

\begin{tabular}{|c|c|c|c|}
\hline Prefarbi: & nič & $\begin{array}{l}\text { dobre, } \\
\text { zle }\end{array}$ & spolu \\
\hline zle & 33 & 1471 & 1504 \\
\hline dobre alebo nič & 11 & 611 & 622 \\
\hline
\end{tabular}

hodnota $\chi^{2}: \quad 0,3934$

hladina v́zznamnosti: $\quad 0,5305$

Tab. 3: Kontingenčná tabul'ka pre hypotézu $1 A$.

Pre overenie hypotézy $1 \mathrm{~B}$ sme zostavili Tab. 4. Hodnota $\chi^{2}$ nás oprávňuje zamietnut' nulovú hypotézu (na zvolenej hladine významnosti 0,05), a teda tvrdit', že medzi takto kategorizovanými odpoved'ami je štatisticky významný vzt'ah.

\begin{tabular}{|l|r|r|r}
\hline & \multicolumn{2}{|c|}{ Kmeň stromu } & \\
\cline { 1 - 2 } Prefarbi: & $\begin{array}{c}\text { nič, } \\
\text { dobre }\end{array}$ & \multicolumn{1}{c}{ zle } & \multirow{2}{*}{ spolu } \\
\cline { 1 - 2 } nič & 41 & 34 & 75 \\
\cline { 1 - 2 } Zle alebo dobre & 840 & 1211 & 2051 \\
\cline { 1 - 3 } & 881 & 1245 & 2126
\end{tabular}

hodnota $\chi^{2}: \quad 5,6051$

hladina významnosti: $\quad 0,0179$

Znamienková schéma:

\begin{tabular}{|l|c|c|}
\hline & \multicolumn{2}{|c|}{ Kmeň stromu } \\
\hline Prefarbi: & $\begin{array}{c}\text { nič, } \\
\text { dobre }\end{array}$ & zle \\
\hline nič & + & - \\
\hline zle alebo dobre & - & + \\
\hline
\end{tabular}

Tab. 4: Kontingenčná tabul'ka pre hypotézu $1 B$.

Znamienková schéma poukazuje na to, že hodnota nič-nič alebo dobre (teda, že sút'ažiaci riešil úlohu Prefarbi nesprávne a úlohu Kmeň stromu riešil správne alebo ju neriešil) je mierne vyššia než očakávaná. Je preto možné, že sút’ažiaci boli čiastočne ovplyvnení svojou nesprávnou odpoved'ou spred roka. Avšak daný jav pozorujeme len u malého počtu sút'ažiacich, preto by sa mal $\mathrm{v}$ budúcnosti ešte preskúmat' napríklad metódou dotazníkov pre konkrétnych učitelov a žiakov a pri ich analýze prípadne zapojit' aj niektoré metódy kvalitatívneho výskumu.

\section{Ciel’ 2 - analýza najt’ažšej úlohy}

Úloha Zmena textu bola podl'a výsledkov riešenia žiakov najtažšou úlohou tohtoročnej sút'aže:

Mišo v programe Kazitext napísal: Bobor kreslí hrad

Potom stlačil tlačidlo otoč slová

Program jeho text zmenil tak, že každé slovo prepísal po písmenkách odzadu.

Mišo potom ešte stlačil tlačidlo otoč všetko. Program teraz jeho celý text prepísal po písmenách odzadu.

Ako vyzerá Mišov text teraz?

a) Bobor kreslí hrad

b) hrad kreslí Bobor 
c) roboB ílserk darh

d) darh ílserk roboB

Len $20 \%$ žiakov ju vyriešilo správne, čo je teoreticky horší výsledok, než náhodné tipovanie. Navyše sme zaradili úlohu ako l'ahkú, teda sme sa výrazne pomýlili v odhade jej obtiažnosti.

Zmena textu - volba distraktorov

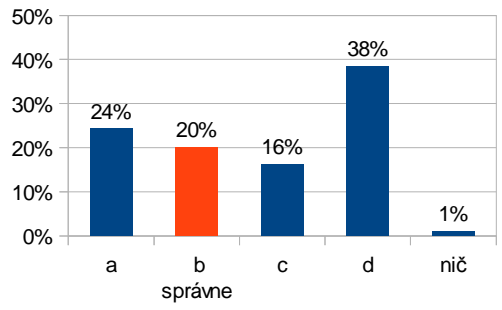

Obr. 4: Vol'ba jednotlivých odpovedí. Správna odpoved' je b, ale najčastejšie zvolená odpoved' je d (darh ílserk roboB) a aj odpoved' a (Bobor kresli hrad) bola volená častejšie než správna odpoved'.

Obr. 4 ukazuje, že sútažiaci výrazne najviac volili odpoved' d, ktorá aplikuje operáciu Otoč všetko na pôvodný text. Preto sme si stanovili hypotézu 2 (vid' vyššie vodseku Ciele výskumu a výskumné hypotézy), že žiaci nepochopili vysvetlenie fungovania tlačidiel.

Hypotézu sme sa snažili overit' pomocou cielenej ankety pre učitel'ov, ktorí mali úspešných sút’ažiacich, ktorí ale odpovedali nesprávne na danú úlohu.
V tejto ankete nám však zo 126 rozposlaných dotazníkov odpovedali len traja učitelia. Tento nepomer si vysvetl'ujeme pomerne dlhým intervalom medzi sút’ažou a dotazníkom. Dotazník teda prišiel v čase, ked' už učitelia nemali chut' sa vracat' $\mathrm{k}$ sút'aži. Uvádzame odpovede troch učitel'ov (podčiarknutie dodali autori článku):

Učitel' 1: „Dokonca som mal chybu v tej otázke aj ja :-). Príćina bola velmi jednoduchá: čítanie sporozumením. Nepostrehli sme rozdiel medzi „každé slovo“ $a$,cely text". Podl'a mňa to bola dobrá úloha. Aj ja sa stále učím pozornejšie čítat' :-)" “"

Učitel' 2: „Možno by som navrhla najskôr uviest', čo robi ktoré tlačidlo, až potom formulovat' zadanie: Mišo urobil toto a potom toto. Ako vyzeral výsledný text? Myslím, že žiakom robilo problémy sledovat' líniu zadania, ked' priamo $z$ formulácie zadania mali aj zistit, ako funguje ktoré tlačidlo. Sama som to musela trikrát prečítat'..."

Učitel' 3: „Žiačka, ktorá mala 72 bodov a tiež túto úlohu vypracovala nesprávne, napísala svoje odôvodnenie v žiackej ankete...

Pýtala som sa aj chlapca, ktorý mal 53,35 bodov, skúšal to vyriešit' znova a na moje prekvapenie úlohu bez problémov vyriešil správne. "

Prvý postreh učitel'a upozorn̆uje na problém, ktorý majú žiaci (a aj dospelí) s pozorným čítaním zadania. Vd’aka druhému postrehu, 
ktorý považujeme za najcennejší, sme si uvedomili, že v úlohe je súčasne uvedená informácia o tom, ako tlačidlá fungujú a čo s nimi robil Mišo. Aj toto môže byt' jedna z príčin nesprávneho riešenia úlohy. Tretí učitel' motivoval žiačku, aby sa vyjadrila $\mathrm{v}$ žiackej ankete (vid' d'alej).

$\mathrm{V}$ d'alšom sme analyzovali aj reakcie žiakov v žiackej ankete. Tú môže vyplnit' žiak ked' si prezerá svoje výsledky asi týždeň po sút’aži. Tento rok vyplnilo aspoň čast' ankety 1135 sút’ažiacich, z toho 605 Benjamínov a z toho 247 zanechalo aj textovú poznámku, z nich 16 sa aspoň čiastočne týkalo úlohy Zmena textu. Z nich 6 komentárov bolo dopísaných až potom, ako sme rozoslali dotazník učitel'om. Teda títo žiaci zrejme dopísali komentár až na popud od svojho učitel'a, ktorý dostal našu anketu.

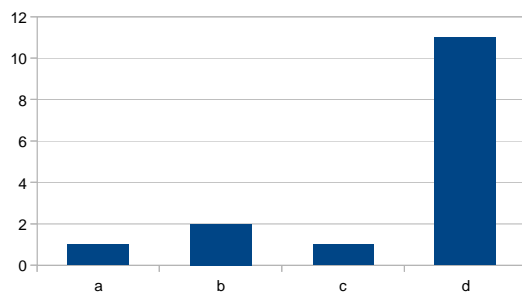

Obr. 5: Vol'ba jednotlivých odpovedí medzi sútažiacimi, ktorí napísali poznámku k úlohe.

Obr. 5 zobrazuje frekvenciu odpovedí medzi tými 15 žiakmi, ktorí nám napísali poznámku $\mathrm{k}$ úlohe.
Vidíme, prevažná väčšina vybrala odpoved' d.

\begin{tabular}{l|r} 
Nerozumel/a & 3 \\
\hline Pomýlil/a sa & 4 \\
\hline Zle prečítal/a & 5 \\
\hline Nepáčila sa & 1 \\
\hline
\end{tabular}

Tab. 5: Frekvencia jednotlivých vyjadrení v texte poznámky.

Tab. 5 zobrazuje frekvenciu jednotlivých vyjadrení v texte poznámok. Vidíme, že prevažná väčšina sa snaží vysvetlit' svoje zlyhanie nejakým spôsobom racionalizovania si svojho počínania. Zaujímavé je, že respondent, ktorý uviedol, že sa mu úloha nepáčila (teda použil iracionálny argument), ju vyriešil správne.

Odpovede poukazujú na to, že naša Hypotéza 2 môže vysvetl'ovat' vel'ké množstvo nesprávnych riešení - mnohí žiaci nesprávne pochopili zadanie úlohy, teda väčšinou nepochopili vysvetlenie fungovania tlačidiel.

Z odpovedí sa dalo vyčítat' aj niekol'ko spôsobov, ako sa dalo dopracovat' k odpovedi d. Prekvapilo nás, že žiaci väčšinou neuvádzali najjednoduchší spôsob - že aplikovali druhé tlačidlo na pôvodný text a nie na text už zmenený prvým tlačidlom.

Žiak 1: „Ja som pochopil úlohu Zmena textu takto: Otoč slová: roboB ílserk darh Otoč písmenká: darh islerk roboB pri obidvoch tlačidlách bolo napísané napíše odzadu, preto som to pochopil, že 
ked' je raz otočené dozadu a otočím to ešte raz, tak to smerom dozadu ostane a nevráti sa to naspät." “

Žiačka 2: „Napísala som bobor kresli hrad na papier a potom som si to napísala od zadu a našla som tam takú odpoved' tak som ju dala ako správnu."

Žiak 3: „ÚLOHA ZMENA TEXTU - zle som prečítal zadanie, prehodil som slová $v$ texte a potom otočil"

Žiak 4: „ÚLOHA ZMENA TEXTU - ZLE SOM SI PRECITAL ZADANIE,V PRVOM KROKU SOM ZMENIL NAJSKOR PORADIE SLOV, AZ POTOM SOM TO OTOCIL“"

Žiačka 5: „V úlohe Zmena textu som sa zmýlila $v$ tom, že prvý príkaz OTOČ SLOVÁ som spravila $2 x$ (1.x - roboB ílserk darh; $2 . x-B o-$ bor kresli hrad) a až potom som spravila druhý príkaz OTOČ VŠETKO a dostala som darh ílserk roboB. Ja som postupovala tak, že som si prečítala prvú vetu po príkaz OTOČ SLOVÁ a otočila som ich. Potom som čítala d'alej, že program text zmenil tak, že každé slovo prepísal po písmenkách odzadu, tak som to spravila zase aj ja. A až potom som pokračovala na to druhé tlačidlo - OTOČ VŠETKO. Preto mi vyšla možnost’ D. “

Odpoved' Žiaka 1 nie je l'ahké pochopit', argumentuje akýmsi pocitom o neotáčaní už otočeného.

Žiačka 2 zrejme aplikovala len druhé tlačidlo.
Texty žiakov 3 a 4 sú takmer identické (sú z tej istej školy), poukazujú na postup, ktorým možno získat' výsledok d - Najprv prehodím poradie slov a potom ich ešte po jednom otočím.

Žiačka 5 Podáva úplne iné vysvetlenie - $\mathrm{z}$ textu pochopila, že má jednotlivé slová otočit' dvakrát (teda text vrátit' do pôvodnej podoby) a až potom aplikovat' druhé tlačidlo. Na túto žiačku sa odvoláva vo svojej odpovedi Učitel' 3.

Ked'že mnohé problémy zjavne spôsobila formulácia úlohy, chceli sme si ešte raz ozrejmit' ako sa jej zadanie menilo $\mathrm{v}$ procese vytvárania a modifikovania úloh.

Pôvodne úlohu do databázy vložil zástupca Českej Republiky Jiří Vaníček. Poslal takýto text:

Pepík wrote a sentence "Cogito ergo sum" in a text editor. Then he rewrote it into the second line this way: he took words consecutive and wrote every word backwards. Then he rewrote the whole sentence from 2 nd line to the $3 r d$ line backwards.

How the text in the 3rd line looked like?
A) Cogito ergo sum
B) sum ergo Cogito
C) otigoC ogre mus
D) mus ogre otigoC

Authorship: Jiri Vanicek 
$\mathrm{V}$ procese evaluácie a editovania úloh na workshope Bebras boli k nemu pripísané dva komentáre:

It needs some work on rewriting in more understandable way (skipping numbers of lines), it is crucial that there is no example!

We like it but now it's not funny for children.

Neskôr bol text upravený v zmysle prvého komentára účastníkmi workshopu takto:

Beaver Berton wrote the sentence "Cogito ergo sum" in a text editor. Then he rewrote it this way: he took words consecutively and wrote every word backwards. Then, he rewrote the modified sentence in another way: he wrote the whole sentence backwards. What did he obtain at the end?
a) Cogito ergo sum
b) sum ergo Cogito
c) otigoC ogre mus
d) mus ogre otigoC

$\mathrm{K}$ úlohe bola pripojený tento komentár:

If there is a strong possibility that word backwards would not be understandable for children it should be explained, for example: first he wrote the last letter and so on.

Vidíme, že pôvodná myšlienka postupného písania textov do viacerých riadkov sa zmenila na prepisovanie textu na mieste.

$\mathrm{Z}$ tohto textu sme vychádzali pri preklade a adaptácii úlohy pre slo- venskú sút’až. Pôvodný text sme si nepozreli lebo účelom workshopu je to, aby boli poskytnuté lepšie texty než boli tie pôvodné. Nášmu kolektívu sa nepáčilo, že Berton prepisuje text na mieste ručne jednak preto, že taká činnost' vyzerá dost' nezmyselne, jednak preto, že by sa l'ahko pomýlil. Preto sme vymysleli, že prepisovat' bude počítač - program Kazitext, do ktorého stačí napísat' pôvodnú vetu a stlačit' nejaké tlačidlá - vid' slovenské znenie uvedené na začiatku odseku 5.

Zaujímalo nás aj to, ako upravili organizátori českej sút’aže Bobřík informatiky. Ich text je takýto (vid' [3]):

Štěpka si hrála s počítačem.

Napsala $v$ textovém editoru název města, kde bydlela:

\section{Ústí nad Labem}

Do druhého řádku prepsala první rádek takto: brala jedno slovo po druhém a každé napsala pozpátku (můj pes -> jům sep).

Do třetího ř́dku prepsala druhý rádek tak, že jej celý napsala pozpátku (můj pes -> sep jům).

Jak vypadal text ve třetím řádku?

a) mebaL dan ítsÚ

b) Ústí nad Labem

c) Labem nad Ústí

d) ítsÚ dan mebaL

Vidíme, že text vychádza z pôvodného návrhu (písanie po riadkoch), neakceptuje teda zmeny vykonané na workshope. Je však zmenený pridaním vysvetlenia 
jednotlivých operácií. Napriek tomuto vysvetleniu však úspešnost' riešenia bola len $30 \%$ aj ked' bola úloha zaradená vo vyššej vekovej kategórii (Kadet).

Ked' spojíme naše výsledky $\mathrm{z}$ analýzy ankiet a analýzy zmien v texte, zdá sa nám, že naša myšlienka zmenit' text úlohy $\mathrm{z}$ ručného prepisovania na automatizované prepisovanie programom Kazitext mohlo byt' príčinou mnohých nejasností. Napriek tomu si myslíme, že smer našej zmeny bol správny, len sme mali íst' ešte d'alej a oddelit' popis fungovania tlačidiel od popisu ich použitia Mišom tak, ako to navrhol Učitel' 2.

\section{Záver}

$\mathrm{Z}$ analýzy úloh nám vyplynulo niekol'ko odporúčaní.

Pri budúcich analýzach úloh treba mat' na zreteli, že sút'ažiaci zrejme len v malej miere, ak vôbec, použijú pri riešení nových úloh vedomosti, ktoré mohli nadobudnút' $\mathrm{v}$ predošlých rokoch. A to napriek tomu, že pred sút'ažou mnohí z nich vyriešia úlohy z archívu našej sút’aže.

Pri tvorbe a preklade budúcich úloh musia autori úloh dbat' na to, aby nespájali pri výklade úloh funkciu elementov s postupom ich použitia $\mathrm{v}$ úlohe.

Treba znovu zvážit', aby úlohy ešte pred sút'ažou čítali a riešili napr. študenti učitel'ského štúdia na VŚ, podobne ako to je v Česku. Tí by ešte pred sút'ažou mohli odhalit' problémy $\mathrm{s}$ formuláciou zadania. Doposial' takýto postup nebol na Slovensku použitý z dôvodu lepšieho utajenia úloh.

Žiakom a učitel'om treba nad'alej a možno ešte dôraznejšie pripomínat', že papier a ceruzka sú vel'mi užitočným nástrojom pri riešení úloh sútaže iBobor. Napriek tomu, že je to jasne napísané v pravidlách, je možné, že mnohí učitelia a žiaci neradi používajú takúto ,zastaralú“ pomôcku pri riešení úloh na počítači.

V praxi odhadovania obtiažnosti úloh by bolo zaujímavé vyskúšat' postup navrhovaný autorom článku [4], ktorý však v čase písania članku v roku 2013 ešte prakticky neaplikoval ani on sám. Preto by bolo zaujímavé dozvediet' sa viac o úspechu aplikácii týchto pravidiel, prípadne ich vyskúšat' na väčšom množstve úloh počas nasledujúceho medzinárodného workshopu.

$\mathrm{Na}$ príklade úlohy Zmena textu vidíme, že autori úloh niekedy neakceptujú zmeny vykonané $\mathrm{v}$ ich úlohách počas workshopu. $\mathrm{Na}$ jednej strane im to pravidlá medzinárodného spoločenstva Bebras nezakazujú, na druhej strane je otázne, či by sa nemal výsledok práce workshopu vždy konzultovat's autormi úloh.

\section{Literatúra}

[1] TOMCSÁNYIOVÁ, M. Úlohy sút'aže iBobor zamerané na rôzne stratégie riešenia problémov. Konferencia DidInfo 2010 (CD ROM), 
Banská Bystrica : Univerzita Mateja Bela, 2010, s. 124-130.

[2] TOMCSÁNYIOVÁ, M. Interaktívne úlohy v sútaži Informatický bobor. Konferencia DidInfo 2009, Banská Bystrica : Univerzita Mateja Bela, 2009, s. 174-177.

[3] Bobřík informatiky, web sút'aže (online). [cit. 2014-02-09] URL: <http://www.ibobr.cz>

[4] VAN DER VEGT, W. Predicting the Difficulty Level of a Bebras Task. Olympiads in Informatics, 2013, Vol. 7, s. 132-139. ISSN 1822-7732.

[5] CHRÁSKA, M. Metody pedagogického výzkumu - Základy kvantitativního výzkumu. 1.vyd. Praha: Grada Publishing, 2007, 272 s. ISBN978-80-247-1369-4 doc. PaedDr. Monika Tomcsányiová, $\mathbf{P h D}$. RNDr. Peter Tomcsányi, PhD. Katedra základov a vyučovania informatiky

Fakulta matematiky, fyziky

a informatiky Univerzity Komenského v Bratislave

Mlynská dolina 842 48, Bratislava, $\mathbf{S R}$

Tel: +421 260295220

E-mail: tomcsanyi@slovanet.sk 